\title{
A luta armada no cinema: ficção, documentário, memória.
}

\author{
Maria Cecília Ferreira De Nichile
}

SELIPRANDY, F.

A luta armada no cinema:

ficção, documentário, memória.

São Paulo: Intermeios,

218 p., 2015.

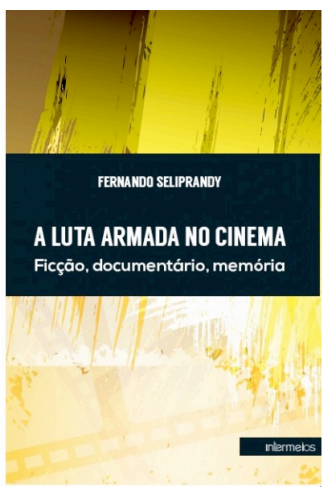

Resumo: No livro A luta armada no cinema: ficção, documentário, memória, Fernando Seliprandy analisa dois filme, O que é isso Companheiro? (1996) e Hércules 56 (2006), que narram um mesmo evento: o sequestro do embaixador norte americano Charles Burke Elbrick, realizado pela ação guerrilheira em curso no Brasil no ano de 1969. Com a descrição do material audiovisual, o livro pretende apreender o uso da imagem fílmica na construção da memória histórica, bem como intenta chegar a possíveis conclusões historiográficas pela observação das relações entre o que é mostrado no discurso cinematográfico e aquilo que está além da narrativa, na conjuntura histórica da qual essas fitas emergiram.

Palavras-chave: cinema; discurso audiovisual; memória histórica.

Abstract: Armed struggle in the cinema: fiction, documentary, memory. - In his book, Fernando Selliprandy analyses two films: Four Days In September (1996) and Hércules 56 (2006), both narrating the same event: the kidnapping of the American Ambassador in Brazil, Charles Burke Elbrick, by the armed resistance, in September 1969. Based on a detailed description 
of the audiovisual material, he intends to understand the use of film image in the construction of historical memory. He also outlines possible historiographic conclusions, observing the relationships between what is shown in the film speech and what is beyond the narrative, in the historical conditions from which these films have emerged.

Palavras-chave: cinema; discurso audiovisual; memória histórica.

Qual significado um filme que carrega consigo os dizeres "baseado em fatos reais" tende a mobilizar? Há uma maior tendência a emprestar credibilidade a uma narrativa que traz imagens tiradas de arquivos históricos? Confia-se mais em depoimentos relatados por partícipes de um evento do que naqueles relatados por terceiros que o testemunharam? Essas são algumas das questões que Fernando Seliprandy tenta responder em seu livro A luta armada no cinema: ficção, documentário, memória.

O cinema é narração por meio de imagens audiovisuais em movimento. Contudo, ele também pode ser compreendido como um documento histórico, uma vez que, independente de ser do gênero documentário ou ficção, traz consigo imagens, valores e discursos que são retirados do mundo natural por um enunciador complexo, formado por toda uma equipe de profissionais do cinema, que interpreta o momento em que vive e o traduz em uma organização sincrética audiovisual que resulta no todo fílmico. A importância do cinema como um pedaço da história é ressaltada por Marc Ferro, ao declarar que "certamente o cinema não é toda a História, mas, sem ele, não se poderia ter o conhecimento de nosso tempo" (FERRO apud MORETTIN, 2007, p. 45).

Tendo como base as palavras de Ferro, o autor analisa duas versões narrativas de um mesmo evento: o sequestro do embaixador norte americano Charles Burke Elbrick, realizado pelo Movimento Revolucionário 8 de Outubro (MR-8) e pela Ação Libertadora Nacional (ALN), em setembro de 1969, com o objetivo de libertar presos políticos. A partir da descrição do material audiovisual de $O$ que é isso companheiro? (Luiz Carlos Barreto, 1997) e Hércules 56 (Sílvio Da-Rin, 2006), o livro pretende chegar a possíveis conclusões historiográficas, posto que esses filmes são enunciações independentes desse passado, não importando tanto a fidelidade do que está sendo figurado na tela do cinema, mas, sim, as relações entre o que é mostrado e aquilo que está além da narrativa, vindo da conjuntura histórica a que se ligam as referidas realizações.

A escolha dos filmes ressalta a diferença entre o gênero ficcional e o documental e as possíveis tensões entre ambos os objetos de reflexão. Enquanto O que é isso companheiro? é um filme de interesse comercial, realizado por um cineasta experiente e com um elenco saído da Rede Globo, por sua vez, Hércules 56 é um documentário sem intuito de lucro, feito por um diretor militante e tendo como elenco pessoas que participaram daquele acontecimento histórico. Se por um lado o primeiro deseja cativar o público com uma narrativa instigante, que abre mão da fidelidade dos fatos em prol do apelo emocional, por outro, o segundo busca retomar a "verdade histórica", mediante uma construção testemunhal. 
O primeiro capítulo trata do uso que faz Barreto daquilo que Roger Odin chamou "instruções documentarizantes", assinalando com isso o recurso a materiais de arquivo e o embaralhamento entre a ficção e a realidade, de modo a criar no espectador um efeito de verdade. Ao mesmo tempo, aponta para o caráter de anti-versão de $O$ que é isso companheiro?, quando se coloca como aquele filme que mostra "a verdadeira versão dos fatos". O livro retoma as definições de Bill Nichols e Robert Stam acerca dos documentários reflexivos que exibem o próprio aparato cinematográfico para discutir de que modo o cinema retoma a História. Indica a intenção do filme de Da-Rin de diluir essa reflexividade, tanto na escolha dos depoentes quanto na forma de editar os diferentes pontos de vista, que no filme se complementam e criam a impressão de um "real" irrefutável, diminuindo assim a potência questionadora da lembrança histórica.

Já o capítulo dois aborda o modo de narrar os eventos de ambos os filmes. Se, por um lado, na ficção, há a construção de um claro antagonismo melodramático, caracterizado pelo maniqueísmo entre o torturador consciente, que se sacrifica pelo que acredita ser um bem maior, e o guerrilheiro frio, que leva outros jovens a se envolverem em ações violentas, do outro lado, no documentário, há o desejo de se criar um relato linear dos acontecimentos, sem suposição de incompatibilidade entre os testemunhos. O autor acredita que a ficção busca um olhar neutro sobre a história, colocando torturadores e guerrilheiros no mesmo plano. Ao mesmo tempo, sustenta que o documentário, ao criar um efeito de totalidade dos depoimentos, quebra as possíveis tensões entre a memória dos partícipes, recusando a diferença das percepções.

O balanço do passado que os discursos fílmicos deixam entrever fica por conta do capítulo três. Aqui, o autor vai aos livros que os dois filmes adaptam. Em O que é isso companheiro, o tom irônico do narrador em off e a seleção de atores saídos da comédia televisiva tendem a reforçar o caráter caricato e cego das personagens, posicionando a luta armada como um equívoco causado pela inexperiência. Por sua vez, em Hércules 56, o mal-estar da discordância quanto aos motivos que levaram à derrota da guerrilha surge amenizado. Essa tensão implícita nos depoimentos se desfaz pela maneira de articular as falas no filme, deixando-se de lado as idiossincrasias da ação guerrilheira para se dar destaque ao sacrifício pessoal como um ato generoso dos partícipes.

Por fim, o quarto capítulo situa as produções cinematográficas em seus contextos históricos, apontando O que é isso Companheiro? como contendo uma moral melodramática que revê o acontecimento histórico de forma a desculpar os atos passados, realizados em nome do que viria a ser a política liberalista brasileira dos anos 1990 . Por outro lado, , assinala a opção de Hércules 56 por edificar uma memória monumentalista do passado da luta armada, de forma a valorizar ativistas que, no momento da feitura do documentário, estavam envolvidos institucionalmente na política do país, pela primeira vez nas mãos do Partido dos Trabalhadores. 
Embora o autor inicie o texto dizendo que tudo é relevante na lógica geral e interna de cada um dos filmes, e que não ignorará as possibilidades significantes do enquadramento, dos movimentos de câmera, da iluminação etc., o livro, bastante descritivo, volta-se mais para o roteiro, para as falas e para caracterização dos personagens do que para uma análise dos dispositivos cinematográficos, concentra-se numa minuciosa observação da articulação das cenas.

O livro A luta armada no cinema: ficção, documentário, memória é interessante para se pensar a influência das imagens fílmicas nos dias de hoje. Demonstra a capacidade do cinema em edificar diferentes memórias do passado histórico e, principalmente, em construir discursos ideológicos que excedem o ato de contar um evento.

Maria Cecília Ferreira De Nichile é produtora e programadora do CineSesc, formada em Audiovisual pela ECA-USP. É mestranda do Programa de Estudos Pós Graduados em Comunicação e Semiótica da PUC-SP.

cicanic@gmail.com

\section{Referências}

MORETTIN, Eduardo. O cinema como fonte histórica na obra de Marc Ferro. In: CAPELATO, Maria H. et. Alli História e cinema. São Paulo: Alameda, 2007. 